\title{
Modeling and Analysis of Solar Photovoltaic Assisted Electrolyzer-Polymer Electrolyte Membrane Fuel Cell For Running a Hospital in Remote Area in Kolkata, India
}

\author{
Kamaljyoti Talukdara* \\ ${ }^{a}$ Department of Mechanical Engineering, Bineswar Brahma Engineering College,Kokrajhar-783370Assam,India
}

\begin{abstract}
The present work consists of the modeling and analysis of solar photovoltaic panels integrated with electrolyzer bank and Polymer Electrolyte Membrane (PEM) fuel cell stacks for running different appliances of a hospital located in Kolkata for different climatic conditions. Electric power is generated by an array of solar photovoltaic modules. Excess energy after meeting the requirements of the hospital during peak sunshine hours is supplied to an electrolyzer bank to generate hydrogen gas, which is consumed by the PEM fuel cell stack to support the power requirement during the energy deficit hours. The study reveals that 875 solar photovoltaic modules in parallel each having 2 modules in series of Central Electronics Limited Make PM 150 with a $178.537 \mathrm{~kW}$ electrolyzer and 27 PEM fuel cell stacks, each of $382.372 \mathrm{~W}$, can support the energy requirement of a 200 lights (100 W each), 4 pumps (2 kW each), 120 fans(65 W each) and 5 refrigerators (2 kW each)system operated for 16 hours, 2 hours, 15 hours and 24 hours respectively. 123 solar photovoltaic modules in parallel each having 2 modules in series of Central Electronics Limited Make PM 150 is needed to run the gas compressor for storing hydrogen in the cylinder during sunshine hours.
\end{abstract}

Keywords: Central Electronics Limited, Electrolyzer, PEM, PM 150, Solar photovoltaic.

Article History: Received Feb $5^{\text {th }} 2017$; Received in revised form June $2^{\text {nd }} 2017$; Accepted June 28 $8^{\text {th }} 2017$; Available online

How to Cite This Article: Talukdar, K. (2017). Modeling and Analysis of Solar Photovoltaic Assisted Electrolyzer-Polymer Electrolyte Membrane Fuel Cell For Running a Hospital in Remote Area in Kolkata,India. International Journal of Renewable Energy Development, 6(2), 181-191.

https://dx.doi.org/10.14710/ijred.6.2.181-191

\section{Introduction}

Demand for electricity and the standard of living are increasing day by day. However, power in the form of electricity is not available in plenty of remote areas like villages. Many people have worked for providing power and useful technology to remote areas and areas where power is not easily available. Chow et al (2006) developed hybrid PVT (photovoltaic-thermal) technology using water as the coolant in order to improve the energy performance of the photovoltaic system in residential areas. Nfah et al (2008) simulated off-grid generation options for remote villages in Cameroon using a load of $110 \mathrm{kWh} /$ day and $12 \mathrm{kWp}$. Chaurey \& Kandpal (2010) used solar home systems for providing basic electricity services to rural households that are not connected to electricity grid. Elhadidy (2002) analysed hourly wind-speed and solar radiation measurements made at the solar radiation and meteorological monitoring station, Dhahran $\left(26^{\circ} 32^{\prime} \mathrm{N}, 50^{\circ} 13^{\prime} \mathrm{E}\right)$, Saudi Arabia, to investigate the feasibility of using hybrid (wind+solar+diesel) energy conversion systems at Dhahran in order to meet the energy needs of 22-bedroom houses. Similarly authors in reference (Nfah et al. 2007; Wies et al. 2005; Al Suleimani \&Nairb 2000; Manolakos et al. 2001; Zhai et al. 2009; Beck 2007; Saheb-Koussa et al. 2009; Nfah \& Ngundam 2008) used different technologies and powering of appliances in different remote areas.

Hospital is very important for people since many villages do not have hospital. If the village has, it is not having proper facilities like electricity. So if

\footnotetext{
* Corresponding Author: kamaljyoti.talukdar@gmail.com

Phone:919864138090
} 
Citation: Talukdar, K. (2017). Modeling and Analysis of Solar Photovoltaic Assisted Electrolyzer-Polymer Electrolyte Membrane Fuel Cell For Running a Hospital in Remote Area in Kolkata, India. Int. Journal of Renewable Energy Development, 6(2), 181-191, https://doi.org/10.14710/ijred.6.2.181-191

$\mathrm{P}$ a g e | 182

somehow electricity can be supplied to hospital in remote villages, village people could be cured without going to town or city. New technologies can be used for assisting the functioning of hospitals. Yoshida et al (2007) used rational method to determine the system structure and operational strategies for the energy supply system for a hospital based on the optimization approach. Paksoy et al (2000) designed a system using solar energy in combination with Aquifer Thermal Energy Storage (ATES) that conserved a major part of the oil and electricity used for heating or cooling the Cukurova University, Balcali Hospital in Adana, Turkey. Similarly, authors in references (Bizzarri \& Morini 2004; Bizzarri \& Morini 2006; Al-Karaghouli \& Kazmerski 2010) used different technologies for running and assisting hospitals.

The present work in this paper deals with the use of solar photovoltaic system assisted PEM electrolyzer fuel cell for powering a hospital. Many works on fuel cell application and solar hydrogen systems had been done. Wu et al (2005) presented an integrated system framework for fuel cell-based distributed energy applications. Veziroglu \& Macario (2011) highlighted some of the research and developmental work, which had occurred in the past five years on fuel cell vehicle technology, with a focus on economic and environmental concerns. Similarly, authors in references (Kelly et al 2011; Solis et al 2010; Dorer et al 2005; Hawkes et al 2006; El-Shatter et al 2002; Shapiro et al 2005; Galli \& Stefanoni 1997; Uzunoglu et al 2009; Barbir 2005; Kelly et al 2008; Zervas et al 2008) used different technologies based on fuel cells for useful and beneficial purposes.

From the mentioned reviews a considerable work of powering remote areas, powering health clinics and on fuel cell has been done,yet no work on powering health clinic by using solar photovoltaic integrated with electrolyzer PEM fuel cell has been done.

Solar Radiation $(\mathrm{G})$

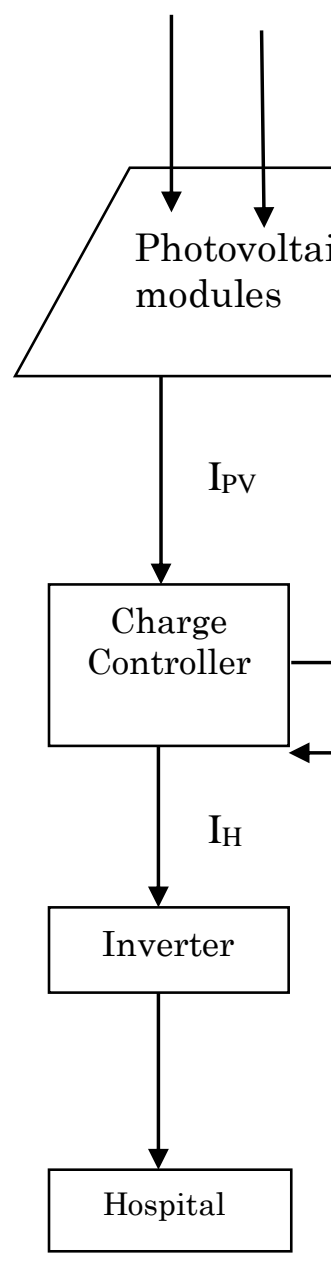

Solar Radiation (G)
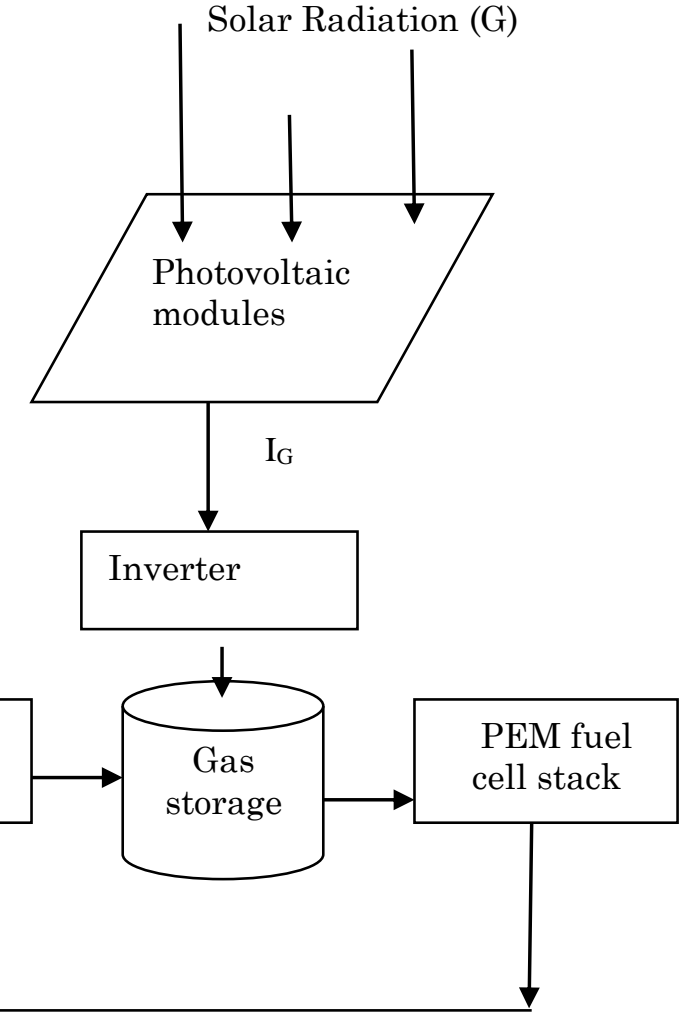

$\mathrm{I}_{\mathrm{H}}-\mathrm{IPV}$

Fig.1. Schematic view of proposed integrated configuration system. 
2. Description of combined solar photovoltaic assisted electrolyser-PEM (polymer electrolyte membrane) fuel cell

The system configuration consists of solar photovoltaic modules, charge controller, PEM electrolyzer, gas storage cylinder, PEM fuel cell stacks and two inverters as shown in Fig.1. When enough sunlight is available, sun rays fall on solar photovoltaic modules and generate current IPv. Some amount of current required for hospital $\left(\mathrm{I}_{\mathrm{H}}\right)$ goes through an inverter to operate various appliances of the hospital. The excess current $\left(\mathrm{I}_{\mathrm{PV}}-\mathrm{I}_{\mathrm{H}}\right)$ after meeting the requirements of the hospital goes to PEM electrolyzer. In electrolyzer water is present which gets dissociated into hydrogen and oxygen. The hydrogen gas generated in electrolyzer is stored in gas compressor. For pressurization of the hydrogen gas owing to low mass density, which requires a very large storage tank, the compressor derives its electrical energy $\left(\mathrm{I}_{\mathrm{G}}\right)$ from solar photovoltaic modules and operates only when electrolyzer is in operation.

When enough sunshine is not available i.e. deficient current $\left(\mathrm{I}_{\mathrm{H}}-\mathrm{IPV}\right)$ comes from the PEM fuel cell stack. The hydrogen required for running the fuel cell is obtained from gas storage cylinder which gets stored during sufficient solar radiation from the electrolyzer.

\section{Modeling}

\subsection{Modeling of solar photovoltaic system}

The electrical energy was generated by harnessing solar energy using photovoltaic modules. In the present work Central Electronics Limited Make PM150 (Solar photovoltaic modules pm 150 2011) solar photovoltaic module has been used. The single cell terminal current is given by (Chenni et al 2007):

$i_{P V}=i_{L}-i_{D}$

Where $i_{L}$ is the light current generated by a solar cell as a function of solar radiation $(\mathrm{G})$ and $i_{D}$ is the diode current.

The light current generated from a photovoltaic module at any given intensity of solar radiation and temperature is given by (Chenni et al 2007):

$i_{L}=\left(\frac{G}{G_{\text {ref }}}\right)\left(i_{\text {scref }}+\mu_{\text {isc }}\left(T_{\bmod \text { ule }}-T_{\bmod \text { uleref }}\right)\right)$

Where $G, G_{\text {ref }}$ is the solar radiation at actual (Tiwari 2004) and reference condition $\left(1000 \mathrm{~W} / \mathrm{m}^{2}\right)$ (Solar photovoltaic modules pm 150 2011) respectively, $i_{\text {scref }}$-short circuit current at reference condition(A)(Solar photovoltaic modules pm 150
2011), $\mu_{i s c}$-manufacturer supplied temperature coefficient of short circuit current(A/K) (Solar photovoltaic modules pm 150 2011), $T_{\bmod u l e}$ and $T_{\text {moduleref }}$ module temperature at actual and at reference condition $(\mathrm{K})($ Solar photovoltaic modules pm 150 2011).

The module temperature is a function of ambient temperature $\left(T_{\text {ambient }}\right)$, wind speed $\left(v_{f}\right)$ and solar radiation(G) and given by (Chenni et al 2007):

$$
\begin{aligned}
& T_{\bmod u l e}(K)=\left(0.943 \times T_{\text {ambient }}+0.028 \times G\right. \\
& \left.-1.528 \times v_{f}+4.3\right)+273.15
\end{aligned}
$$

Where, $T_{\text {ambient }}$ is in ${ }^{0} \mathrm{C}$ (Tiwari 2004), $G$ in $\mathrm{W} / \mathrm{m}^{2}$ (Tiwari 2004), $v_{f}$-wind speed in $\mathrm{m} / \mathrm{s}$ (Wind speed in Kolkata,West Bengal 700001,India 2014).

The diode current in equation (1) is a function of reverse saturation current and given by(Chenni et al.2007):

$i_{D}=i_{\text {sat }}\left[\exp \left(\frac{q\left(V+i_{P V} R_{s}\right)}{\gamma k T_{\text {module }}}\right)-1\right]$

Where $i_{\text {sat }}$ - reverse saturation current(A), $q$-electron charge $\left(1.6 \times 10^{-19} \mathrm{C}\right), \quad V$-terminal voltage $(\mathrm{V}), R_{S}$ series resistance, $\gamma$-shape factor, $k$-Boltzamann constant(1.38 x 10-23 $\mathrm{J} / \mathrm{K})$.

$i_{\text {sat }}=i_{\text {satref }}\left(\frac{T_{\text {mod ule }}}{T_{\text {mod uleref }}}\right)^{3} \exp \left[\left(\frac{q \varepsilon_{G}}{k A}\right)\left(\frac{1}{T_{\text {mod uleref }}}-\frac{1}{T_{\text {mod ule }}}\right)\right]$

(5)

Where A-completion factor, $\varepsilon_{G}$-material bandgap (1.12eV for $\mathrm{Si}$ ), and

$i_{\text {satref }}=i_{\text {scref }} \times \exp \left(\frac{-q V_{\text {ocref }}}{k \gamma T_{\text {mod uleref }}}\right)$

Where $V_{\text {ocref }}$-open circuit voltage at reference condition (Solar photovoltaic modules pm 150 2011). $i_{\text {sat }}, i_{\text {sarref }}$ is taken from Chenni et al (2007).

Shape factor $(\gamma)$ which is a measure of cell imperfection is given by Chenni et al (2007):

$\gamma=A \times N C S \times N_{S}$ 
Citation: Talukdar, K. (2017). Modeling and Analysis of Solar Photovoltaic Assisted Electrolyzer-Polymer Electrolyte Membrane Fuel Cell For Running a Hospital in Remote Area in Kolkata, India. Int. Journal of Renewable Energy Development, 6(2), 181-191, https://doi.org/10.14710/ijred.6.2.181-191

$\mathrm{P}$ a g e | 184

Where $A, N C S, N_{S}$ is completion factor, number of cells connected in series in a single module (specified by manufacturer of the module) and number of modules connected in series of the entire photovoltaic array respectively.

$$
N_{S}=\frac{V_{\text {system }}}{V_{\text {mod ule }}}
$$

Where $V_{\text {system }}$ is the system voltage of the photovoltaic

array (considered $48 \mathrm{~V}$ in present study) and $V_{\text {mod ule }}$ is the voltage obtained from single module.

Table 1 shows the specification of various equipment used in the hospital.

Table 1

Operating load parameters of combined PV and electrolyzer-PEM fuel cell system

\begin{tabular}{cccc} 
Equipments(o) & No. of items(n) & Wattage(P)(in W) & Operating hours(t) \\
\hline Lights & 200 & 100 & 16 \\
Pump & 4 & 2000 & 2 \\
Fans & 120 & 65 & 15 \\
Refrigerator & 5 & 2000 & 24 \\
\hline
\end{tabular}

The total daily electrical load $(\mathrm{Ah})\left(i_{o}\right)$ due to operation of equipments mentioned in table 1 is given by:

$i_{O}=\frac{n \times P_{O} \times t}{V_{\text {system }} \times P F}$

Where io- electrical load of an equipment, Po-power rating of an equipment, $t$-operating hours of an equipment and $n$-number of items, $P F$-power factor (considered 0.85).

The total daily electrical load(Ah) $\left(i_{\text {total }}\right)$ consisting of lights, pumps, fans and refrigerator can be given as:

$i_{\text {total }}=\frac{\sum i_{o}}{\eta_{\text {inverter }}}$

Where $\eta_{\text {inverter }}$-inverter efficiency (0.85)

The design current required from photovoltaic $\operatorname{array}\left(i_{s p v}\right)$ is given by(Ganguly et al. 2010):

$i_{\text {spv }}=\frac{i_{\text {total }} \times D F}{\text { peaksunshinehours } \times \eta_{\text {ch } \arg \text { econtroller }}}$

Where DF is the de-rating factor of photovoltaic module (Telecommunication Engineering Centre (TEC), New Delhi 2011) is 1.25, $\eta_{\text {ch arg econtroller }}$ is charge controller efficiency (Telecommunication Engineering Centre (TEC), New Delhi 2011) is 0.85, peak sunshine hours is considered 7 hours per day(Patra \& Datta 2009).

Number of PV modules connected in parallel $(\mathrm{Np})$ is given by:

$N_{p}=\frac{i_{s p v}}{i_{m p}}$

Where $i_{m p}$ is the maximum current available from single module under peak power condition(Solar photovoltaic modules pm 150 2011)

Net current from solar PV array is:

$$
i_{\text {array }}=i_{p v} \times N_{p}
$$

\subsection{Modelling of PEM fuel cell}

Table 2 shows the input parameters used for modelling fuel cell.

Table 2

Input parameters of fuel cell

\begin{tabular}{ccc} 
Model & Parameter & Value \\
\hline & $\begin{array}{c}\text { Exchange current } \\
\text { density }\left(\mathrm{H}_{2}\right)\end{array}$ & $10^{-4} \mathrm{~A} / \mathrm{cm}^{2}$ (Hayre et al.2006) \\
Fuel cell & $\begin{array}{c}\text { Charge transfer coefficient } \\
\text { of reaction } \\
\text { Cell effective area }\end{array}$ & 0.5 (Hayre et al.2006) \\
& Operating current density & $100 \mathrm{~cm}^{2}(\mathrm{Pal} 2004)$ \\
& & $0.1 \mathrm{~A} / \mathrm{cm}^{2}(\mathrm{Pal} 2004)$
\end{tabular}

The net voltage $\left(V_{f c}\right)$ of a PEM fuel cell is given by(Ganguly et al. 2010):

$V_{f c}=V_{\text {nerst }}-V_{\text {activation }}-V_{\text {ohmic }}-V_{\text {concentration }}$ 
Nerst potential ( $V_{\text {nerst }}$ ) of PEM fuel cell is given by Ganguly et al (2010):

$$
V_{\text {nerst }}=V_{\text {rev }}{ }^{o}+\frac{R^{-} T}{n F} \ln \left(\frac{p_{H_{2}} p_{O_{2}}{ }^{0.5}}{p_{H_{2} O}}\right)
$$

Where $V_{\text {rev }}{ }^{o}$ is the reference reversible potential, $T$ is fuel cell operating temperature $\left(60^{\circ} \mathrm{C}\right.$ in the present study), $F$ is Faraday constant (96500 C/mole), $p$ is the partial pressure of the gases(Pa), $\bar{R}$-universal gas constant $(8.314 \mathrm{~J} / \mathrm{mole}$. K).

Activation voltage $\left(V_{\text {activation }}\right)$ is given by Tafel equation (Hayre et al. 2006):

$$
V_{\text {activation }}=\left(\frac{-\overline{R T}}{\alpha n F}\right) \ln \left(\frac{j_{f c}}{j_{o}}\right)
$$

Where $\alpha$ is the charge transfer coefficient of the reaction (Hayre et al. 2006), $j_{f c}$ and $j_{o}$ being operating current density of fuel cell stack and exchange current density respectively.

Ohmic voltage $\left(V_{\text {ohmic }}\right)$ is given by (Gangly et al. 2010):

$V_{\text {ohmic }}=R \times j_{f c}$

Where $\mathrm{R}$ is the resistance of the polymer membrane (Nafion 117 type) which is given by (Ganguly et al. 2010):

$$
R=\frac{u_{f c}}{\sigma_{f c}}
$$

Where $u_{f c}$ is the thickness of Nafion 117 membrane (Nafion membranes-Fuel cell Etc. 2016), $\sigma_{f c}$ is the conductivity of Nafion 117 membrane depending on water content $(\lambda)$ and fuel cell operating temperature (T) given by (Kandlikar \& Lu 2009):

$$
\sigma_{f c}=(0.5139 \lambda-0.326) \exp \left[1268\left(\frac{1}{303}-\frac{1}{T}\right)\right]
$$

And $\lambda=8.38+0.138 \times(T-273.15)$

Concentration voltage $\left(V_{\text {concentration }}\right)$ is given by Ganguly et al. (2010):
$V_{\text {concentration }}=\left(\frac{\overline{R T}}{n F}\right) \ln \left[\left(\frac{j_{l}-j_{f c}}{j_{l}}\right)\right]$

Where $j_{l}$ is limiting current density of fuel cell and given by (Ganguly et al. 2010):

$j_{l}=\frac{n F D C_{B}}{\delta}$

Where $\mathrm{D}$ is the effective reactant diffusivity within catalyst layer having typical value $10^{-2} \mathrm{~cm}^{2} / \mathrm{s}$ (Hayre et al. 2006), $\delta$ is the electrode(diffusion layer) thickness whose value ranges from 100-300 $\mu$ m (Hayre et al. 2006).

$\mathrm{C}_{\mathrm{B}}$ is the bulk (flow channel) concentration of the reactant given by (Bhagat \& Dhoble 2007):

$C_{B}=\frac{p_{H_{2}}}{R \times \overline{-} \times m_{H_{2}}}$

Where $m_{H_{2}}$ is the mass of hydrogen.

Peak hourly current requirement from fuel cell stack $\left(i_{\text {fuelcell }}\right)$ is given by:

$i_{\text {fuelcell }}=\frac{\text { peakloadcurrent }}{\eta_{\text {ch } \arg \text { econtroller }}}$

In Equation 24 peak load current means the maximum current requirement at any hour during non sunshine hours i.e from 1:00 am to 5:00 am and 7:00pm to 1:00 am.

Number of PEM fuel cell stacks in parallel $\left(N_{\text {fcparallel }}\right)$ can be obtained as shown:

$N_{\text {fcparallel }}=\frac{i_{\text {fuelcell }}}{i_{\text {cell }}}$

Where $i_{\text {cell }}$ is the current generated by single fuel cell, which can be obtained from effective area of each cell, and fuel cell operating current density. $N_{\text {fcseries }}$ is the number of fuel cell connected in series and is given by:

$N_{f c s e r i e s}=\frac{V_{\text {system }}}{V_{f c}}$

The hourly hydrogen consumption of a fuel cell stack $\left(m_{f c}\right)$ at design load is given by (Ganguly et al 2010):

$$
m_{f c}=\frac{i_{\text {fuelcell }} \times N_{\text {fcseries }} \times 3600 \times 2}{2 \times F \times \eta_{\text {fuel }}}
$$

Where $\eta_{\text {fuel }}$-fuel utilization factor in fuel cell (considered 0.9) 
Citation: Talukdar, K. (2017). Modeling and Analysis of Solar Photovoltaic Assisted Electrolyzer-Polymer Electrolyte Membrane Fuel Cell For Running a Hospital in Remote Area in Kolkata, India. Int. Journal of Renewable Energy Development, 6(2), 181-191, https://doi.org/10.14710/ijred.6.2.181-191

P a g e | 186

\subsection{Modeling of PEM electrolyzer}

In electrolyzer excess current after meeting the requirements of the hospital is used for dissociating water into hydrogen and oxygen gas. Table 3 shows the various input parameters used for modeling electrolyzer.

Table 3

List of input parameters of electrolyzer

\begin{tabular}{ccc}
\hline Model & Parameter & Value \\
\hline & Number of cells in stack(in series) & 24 \\
Electrolyzer & Cell area & $86.4 \mathrm{~cm}^{2}($ Dale et al.2008) \\
& Maximum current density & $1.6 \mathrm{~A} / \mathrm{cm}^{2}($ Dale et al.2008) \\
& Dry thickness of membrane & $178 \mu \mathrm{m}($ Dale et al.2008) \\
\hline
\end{tabular}

Table 4

List of input parameters of hydrogen compressor

\begin{tabular}{|c|c|c|}
\hline Model & Parameter & Value \\
\hline & Isentropic efficiency & 0.7(Li et al. 2009) \\
\hline Hydrogen compressor & $\begin{array}{c}\text { Specific heat of hydrogen at constant pressure }\left(\mathrm{C}_{\mathrm{p}}\right) \\
\text { Exit pressure }\end{array}$ & $\begin{array}{l}14.304 \mathrm{~kJ} / \mathrm{kg} . \mathrm{K}(\mathrm{Li} \text { et al. } 2009) \\
200 \mathrm{bar}(\mathrm{Li} \text { et al. } 2009)\end{array}$ \\
\hline
\end{tabular}

The electrolyzer electrical efficiency $\left(\eta_{\text {elec }}\right)$ is defined as the product of the current efficiency $\left(\eta_{i}\right)$ and voltage efficiency $\left(\eta_{\text {voltage }}\right)$ given as(Li et al. 2009):

$$
\eta_{\text {elec }}=\eta_{i} \times \eta_{\text {voltage }}
$$

Where current efficiency $\left(\eta_{i}\right)$ varies with the current passing through the electrolyzer cells $\left(\mathrm{I}_{\mathrm{pv}}-\mathrm{I}_{\mathrm{H}}\right)$ and given by(Li et al. 2009):

$$
\eta_{i}=96.5 \times \exp \left(\frac{0.09}{\left(I_{p v}-I_{H}\right)}-\frac{75.5}{\left(I_{P V}-I_{H}\right)^{2}}\right)
$$

The voltage efficiency is assumed to be $74 \%(\mathrm{Li}$ et al. 2009).

Amount of hydrogen produced (in gm mol) in electrolyzer with $\mathrm{N}_{\text {elec }}$ (number of cell in series) in one hour is given by (Li et al. 2009).

$$
M_{\text {elec }}=\frac{\left(I_{p v}-I_{H}\right) \times N_{\text {elec }}}{2 F} \times \eta_{\text {elec }} \times 3600
$$

\subsection{Modelling of gas compressor}

Hydrogen gas produced in electrolyzer needs to be compressed. For compressing the hydrogen gas energy i.e current is obtained from solar photovoltaic modules integrated with inverter as shown in fig.1. Table 4 shows the various input parameters used for modeling gas compressor.

The power required to run the gas compressor is given by (Li et al. 2009):

$$
W_{C}=\frac{m_{H_{2}} \times C_{p} \times T_{1}}{\eta_{C}}\left[\left(\frac{P_{2}}{P_{1}}\right)^{\frac{\gamma-1}{y}}-1\right]
$$

Where $m_{H_{2}}$-mass flow rate of hydrogen gas in compressor, $C_{p}$-specific heat of hydrogen at constant pressure, $\mathrm{T}_{1}$-gas temperature at compressor inlet, $\mathrm{P}_{1}$ and $\mathrm{P}_{2}$-inlet and exit pressure of hydrogen gas at entry and exit of compressor respectively, $\eta_{C}$-isentropic efficiency of compressor, $\gamma$-isentropic exponent of hydrogen(1.4).

Current required for running the gas compressor $\left(i_{\text {compressor }}\right)$ is given by:

$i_{\text {compressor }}=\sum_{t=6}^{18} \frac{W_{C, t}}{V_{\text {system }} \times P F}$

where $W_{C, t}$-compressor power rating from 6 hours to 18:00 hours.

$i_{\text {compressortotal }}=\frac{i_{\text {compressor }}}{\eta_{\text {inverter }}}$

The design current required from photovoltaic array $\left(i_{\text {spv }}\right)$ given by:

$$
i_{\text {spv }}=\frac{i_{\text {compressortotal }} \times D F}{\text { peaksunshinehours }}
$$

Number of photovoltaic modules needed for running the gas compressor ( $N_{p \text {,compressor }}$ ) is given by: 
$N_{p, \text { compressor }}=\frac{i_{s p v}}{i_{m p}}$

\section{Results and Discussion}

A numerical code in $\mathrm{C}$ was developed for simulating the required combination of solar photovoltaic assisted electrolyzer PEM fuel cell for running a hospital.

Table 5 shows different appliances operated at different hours of a day for all the months i.e. March, May, September and December.

Table 5

Assumed load pattern of appliances

\begin{tabular}{cc|}
\hline $\begin{array}{c}\text { Time span of } \\
\text { day }\end{array}$ & Nature of load \\
\hline 12 AM-7AM & 200 lights +5 refrigerators \\
7 AM-9AM & 200 lights +4 pumps +120 fans +5 \\
refrigerators \\
9AM-5PM & 120 fans +5 refrigerators \\
5PM-10PM & 200 lights +120 fans +5 refrigerators \\
10PM-12AM & 200 lights +5 refrigerators \\
\hline
\end{tabular}

The ratings of different power system components are given in Table 6 . In Table 6 it is seen that number of photovoltaic modules in parallel is 875 which is obtained from equation 2 where $i_{\text {spv }}$ total is 4198.033 and $i_{m p}$ is $4.8 \mathrm{~A}$. Number of modules in series is given by equation 8 where Vsystem is $48 \mathrm{~V}$ and $V_{\text {module }}$ is the maximum voltage from a given module being $34 \mathrm{~V}$. Electrolyzer input at $48 \mathrm{~V}$ is $178.537 \mathrm{~kW}$ which is taken at $12: 00$ hours (maximum radiation in a day) for the month of May because month May has the highest solar radiation and electrolyzer input will be maximum due to greater production of hydrogen by electrolyzer, hence electrolyzer which works well in May will work well throughout the year. The number of fuel cells in a stack in series is 47 is given by equation no.26 where $\mathrm{Vfc}$ is given by equation no.14 is $1.028 \mathrm{~V}$. The number of fuel cell in stacks in parallel is given by equation no.24 and 25.In equation no.24 peak load current during non-sunshine hours is $228.984 \mathrm{~A}$ which is between 17:00 hours to 22:00 hours. icell is the current obtained from parameters given in Table no. 2.

The maximum output of each fuel cells stack in series is $7.966 \mathrm{~A}$ and power of each fuel cell stack is given by product of $48 \mathrm{~V}$ and $7.966 \mathrm{~A}$ which is 382.372 W. Gas compressor rating at $48 \mathrm{~V}(14.234 \mathrm{~kW})$ is given by equation 31 and is taken from the month of May at 12:00 hours because at this time the hydrogen production is maximum (1189.084 gm.mol) and consumption of power by gas compressor to compress large hydrogen generated by electrolyzer is maximum, Hence gas compressor if it works well in this time and it can work well also throughout the year. The number of photovoltaic modules in parallel for operating the gas compressor is given by equation 35 . The total ispv current for the gas compressor is 588.235 Ah and number of photovoltaic modules in parallel needed is obtained by dividing 588.235 Ah by imp. Current ispv for the gas compressor is taken for the month of May due to the fact that month May has highest solar radiation, hence it will need a more current and more number of photovoltaic modules for generating current to compress a large amount of hydrogen generated by electrolyzer in the month of May. The number of modules in series is obtained by the same method as equation 8 .

Fig. 2, 4, 6, 8 shows the hourly current consumption (load current $\mathrm{Ah}$ ) throughout the day for running the appliances of the hospital by using equation 11. In all the figures it is seen that current consumed in Ah from 10 PM to $7 \mathrm{AM}$ is $181.733 \mathrm{Ah}$ per hour. Similarly, current consumed from 7 AM to 9AM is 277.446 Ah per hour, $9 \mathrm{AM}$ to $5 \mathrm{PM}$ is 107.828 Ah per hour, 5 PM to10 PM is 228.984 Ah per hour. The current consumption will be same for all the months due to the operation of the same number of equipments for the same number of hours shown in Table 5 for all the different months i.e. March, May, September, and December.

Solar photovoltaic (SPV) current generated during sunshine hours (6:00hours to18:00hours) in Figures $2,4,6$,and 8 from the photovoltaic array for the months i.e. March, May, September, and December is obtained from equation 13. It was observed that the trend of SPV current generated increases from 6:00 hours to 12:00 hours and again decreases to 18:00 hours because solar radiation increases from 6:00 hours to $12: 00$ hours and again decreases to $18: 00$ hours.

Table 6

Rating of power system components

\begin{tabular}{|lc|}
\hline \multicolumn{1}{c}{ Components of power system } & Rating \\
\hline No. of photovoltaic modules in parallel $\left(\mathrm{N}_{\mathrm{p}}\right)$ & 875 \\
No. of photovoltaic modules is series $\left(\mathrm{N}_{\mathrm{s}}\right)$ & 2 \\
Electrolyzer input at $48 \mathrm{~V}$ & $178.537 \mathrm{~kW}$ \\
No. of fuel cell in a stack $\left(\mathrm{N}_{\text {fcseries }}\right)$ & 47 \\
No. of fuel cells stacks $\left(\mathrm{N}_{\text {fcparallel }}\right)$ & 27 \\
Maximum output of each fuel cell stack & $7.966 \mathrm{~A}, 382.372 \mathrm{~W}$ \\
Gas compressor rating at $48 \mathrm{~V}$ & $14.234 \mathrm{~kW}$ \\
No. of photovoltaic modules in parallel for & 123 \\
gas compressor $\left(\mathrm{N}_{\mathrm{p}, \text { compressor }}\right)$ & \\
No. of photovoltaic modules in series for gas & 2 \\
compressor & \\
\hline
\end{tabular}

Based on the analysis of Figures 2, 4, 6, and 8 it is seen that months March and September have the same pattern of SPV power generation due to the same amount of solar radiation values from 6:00 hours to 18:00 hours. Month May has highest SPV power generation due to the availability of maximum solar radiation in a year. Month December has lowest 
Citation: Talukdar, K. (2017). Modeling and Analysis of Solar Photovoltaic Assisted Electrolyzer-Polymer Electrolyte Membrane Fuel Cell For Running a Hospital in Remote Area in Kolkata, India. Int. Journal of Renewable Energy Development, 6(2), 181-191, https://doi.org/10.14710/ijred.6.2.181-191

P a g e | 188

SPV power generation due to the availability of lowest solar radiation in a year. The SPV power generated is almost same at 6:00 hours and 18:00 hours in figures $2,4,6$, and 8 due to the same value of solar radiation at 6:00 hours and 18:00 hours. The solar radiation data is taken from Tiwari (2004).

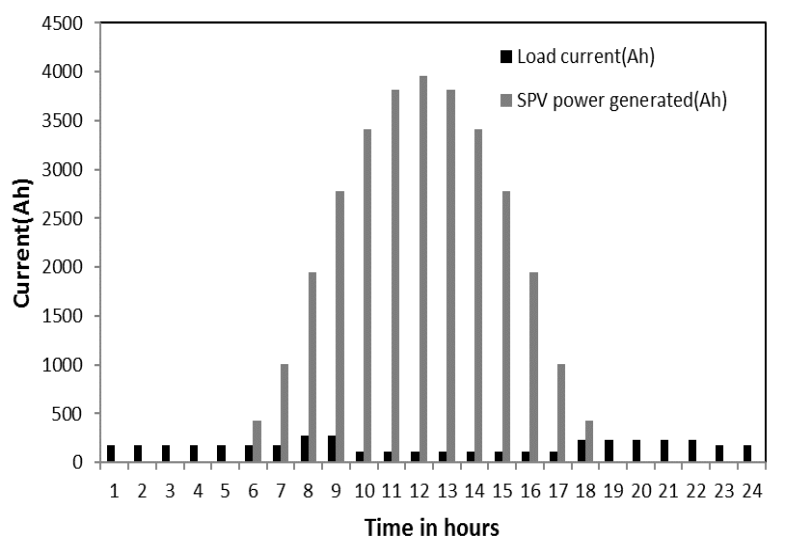

Fig.2 Electrical load variation for the month of March

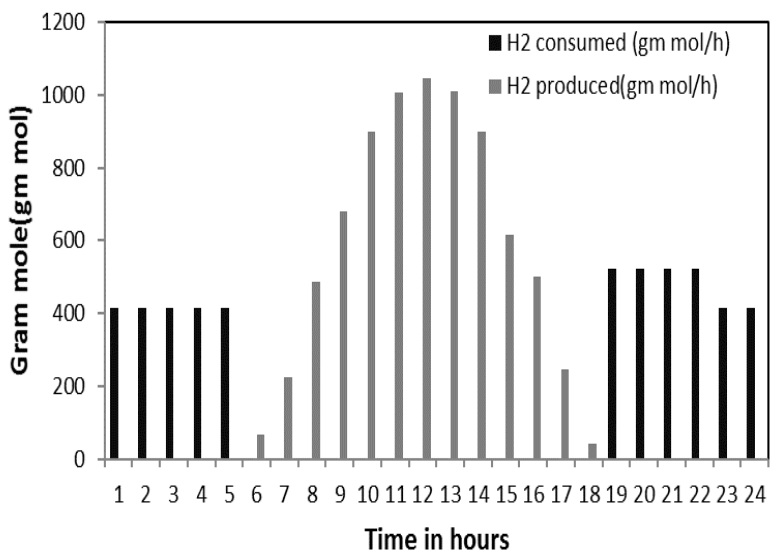

Fig.3 Hydrogen consumption and production pattern for the month of March

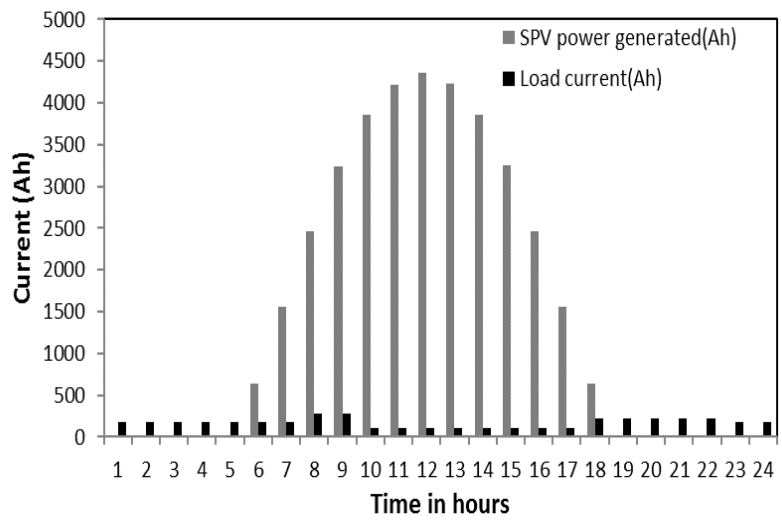

Fig.4 Electrical load variation for the month of May.

In Figs. 3, 5, 7, 9 shows hydrogen consumption (gm mole/hour) by fuel cell stacks which are dependent on the types of equipment operated in given hours shown in Table 5. Hydrogen consumption(gm mole/hour) is same for all the months due to the reason mentioned earlier by fuel cell stacks during non-sunshine hours using equation no. 27 i.e. from 22:00hours-5:00hours is $413.423 \mathrm{gm} \mathrm{mole/hour} \mathrm{and} \mathrm{19:00hours-22:00hours} \mathrm{is}$ 520.913 gm mole/hour.

Figs. 3, 5, 7, 9 also shows hydrogen production (gm mole/hour) using equation no. 30 by electrolyzer from the current generated by photovoltaic modules during sunshine hours(i.e. from 6:00 hours to 18:00 hours).It is seen that hydrogen production increases from 6:00 hours to 12:00 hours and decreases to 18:00 hours. It is due to the fact that solar radiation increases from 6:00 hours to 12:00 hours and again decreases to 18:00 hours. Thus more solar radiation means more amount of current being generated by utilizing to produce more hydrogen by given electrolyzer after meeting the hospital's current requirements.

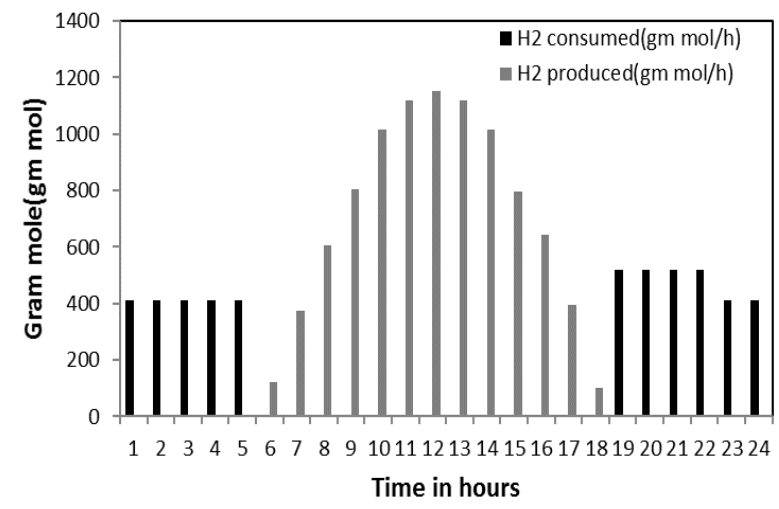

Fig.5 Hydrogen consumption and production pattern for the month of May

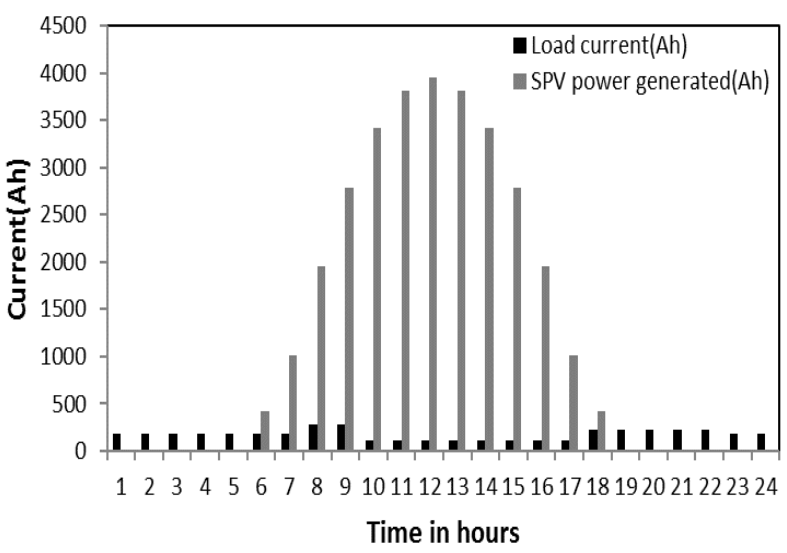

Fig.6 Electrical load variation for the month of September

Based on the analysis of figures3, 5,7, and 9 it is seen that months March and September have the same pattern of hydrogen generation due to the same reason mentioned earlier in Figs. 2,4,6, and 8 for SPV power generation. Month May has highest hydrogen generation and month December has lowest hydrogen generation due to the same reason mentioned in Figs. 
2, 4, 6 and 8 for SPV power generation. It is also seen that hydrogen production is less at 18:00 hours compared to 6:00 hours due to the greater amount of current consumed from 17:00 hours to 22:00 hours which is 228.984 Ah per hour by the hospital as discussed earlier, hence less amount of current is available to electrolyzer for hydrogen production.

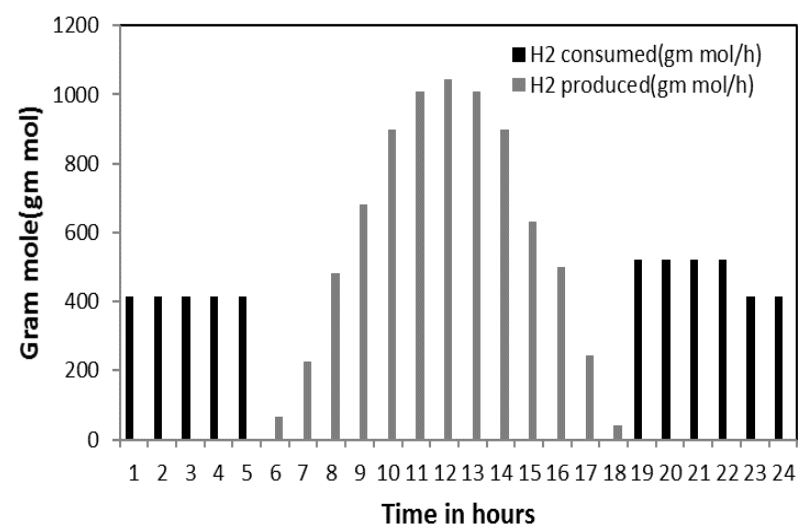

Fig.7 Hydrogen consumption and production pattern for the month of September

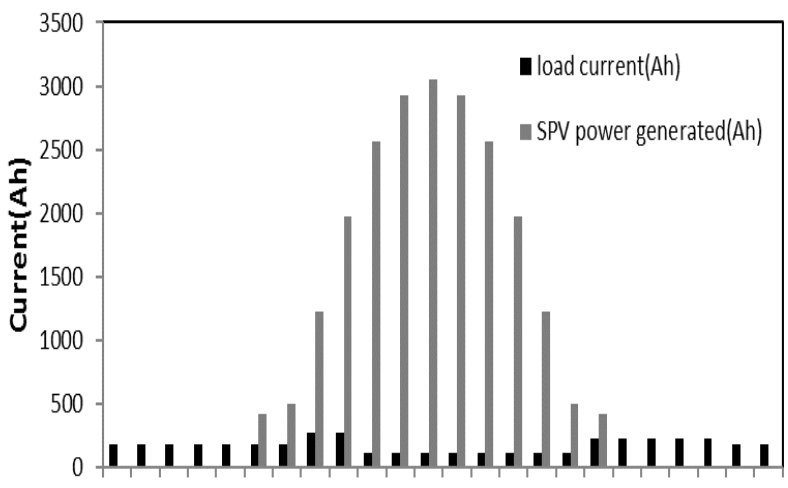

123456789101112131415161718192021222324

Time in hours

Fig.8 Electrical load variation for the month of December

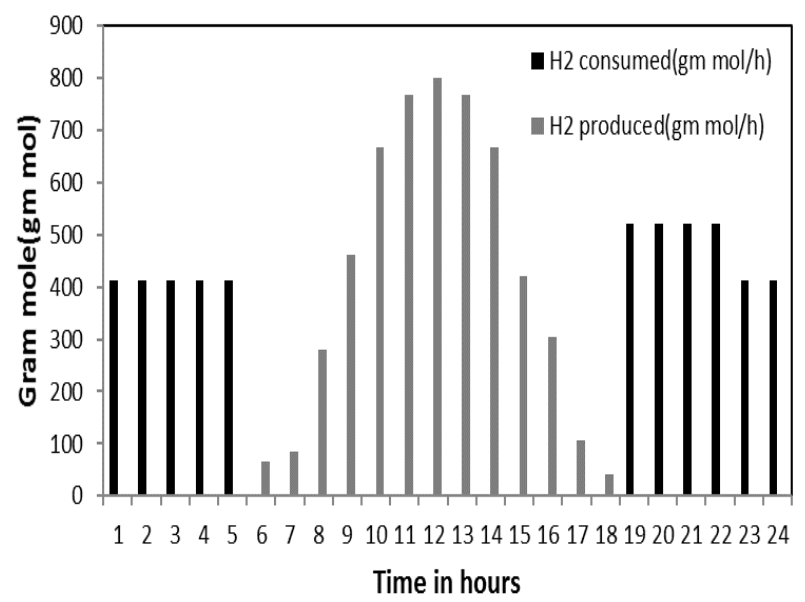

Fig.9 Hydrogen consumption and production pattern for the month of December
The cumulative daylong hydrogen generation in electrolyzer is summation of hydrogen generated from 6:00 hours to 18:00 hours and cumulative consumption of hydrogen in fuel cell stacks is the summation of hydrogen consumption during nonsunshine hours from 19:00 hours to 5:00 hours for different months representing different seasons of a year is shown in Table 7.

Table 7

Cumulative day long gas generation and consumption in different months

\begin{tabular}{lllll}
\hline & \multicolumn{4}{c}{ Month } \\
\cline { 2 - 5 } & March & May & Sept & Dec \\
\hline $\begin{array}{l}\text { Cumulative } \\
\text { daylong H } \\
\text { generation(gm }\end{array}$ & 7920.714 & 9527.437 & 7952.121 & 5596.532 \\
$\begin{array}{l}\text { mol) } \\
\begin{array}{l}\text { Cumulative } \\
\text { daylong H2 } \\
\text { consumption(gm } \\
\text { mol) }\end{array}\end{array}$ & & & & \\
\hline
\end{tabular}

It can be seen that cumulative day long hydrogen consumption is same for all the four months due to operation of same number of equipments for same definite hours throughout the year.

\section{Conclusion}

In the present work appliances of a hospital located in a remote area in Kolkata is operated with the integrated system of solar photovoltaic and electrolyzer-polymer electrolyte membrane fuel cell. It is seen that cumulative hydrogen generation in electrolyzer is more than hydrogen consumption in PEM fuel cell stack of four different months of a year.

A total of 875 solar photovoltaic modules in parallel, 2 modules in series of Central Electronics Limited Make PM 150 with a $178.537 \mathrm{~kW}$ electrolyzer and 27 PEM fuel cell stacks, each of $382.372 \mathrm{~W}$ can support the energy requirement of a 200 lights $(100 \mathrm{~W}$ each), 4 pumps ( $2 \mathrm{~kW}$ each), 120 fans (65 W each) and 5 refrigerators $(2 \mathrm{~kW}$ each)system operated for 16 hours, 2 hours, 15 hours and 24 hours respectively. 123 solar photovoltaic modules in parallel each having 2 modules in series of Central Electronics Limited Make PM 150 is needed to run the gas compressor for storing hydrogen in the cylinder during sunshine hours. If the number of types of equipment and operating hours change, then the configuration of integrated solar photovoltaic and electrolyzer-PEM fuel cell will change

\section{References}

AlKaraghouli,A.,\&Kazmerski,L.L.(2010)Optimization and life-cycle cost of health clinic PV system for a rural area in southern Iraq using HOMER software. Solar Energy, 84,710-714. 
Citation: Talukdar, K. (2017). Modeling and Analysis of Solar Photovoltaic Assisted Electrolyzer-Polymer Electrolyte Membrane Fuel Cell For Running a Hospital in Remote Area in Kolkata, India. Int. Journal of Renewable Energy Development, 6(2), 181-191, https://doi.org/10.14710/ijred.6.2.181-191

$\mathrm{P}$ a g e | 190

Al Suleimani,Z.,\&Nairb,V.R.(2000)Desalination by solarpowered reverse osmosis in a remote area of the Sultanate of Oman.Applied Energy,65(1-4),367-380.

Barbir,F.(2005)PEM electrolysis for production of hydrogen from renewable energy sources.Solar Energy,78(5),661-669.

Beck,M.K.(2007)A comprehensive solar electric system for remote areas.Desalination,209(1-3),312-318.

Bhagat,P.,\&Dhoble,A.(2007)Performance prediction and experimental evaluation of PEM fuel cell.Journal of Institution of Engineers India,88,21-26.

Bizzarri,G.,\&Morini,G.L.(2004)Greenhouse gas reduction and primary energy savings via adoption of a fuel cell hybrid plant in a hospital.Applied Thermal Engineering,24,383-400.

Bizzarri,G.,\&Morini,G.L.(2006)New technologies for an effective energy retrofit of hospitals.Applied Thermal Engineering,26,161-169.

Chaurey,A.,\&Kandpal,T.C.(2010)A techno-economic comparison of rural electrification based on solar home systems and PV microgrids. Energy Policy, 38,3118-3129.

Chenni,R.,Makhlouf,M.,Kerbache,T.,\&Bouzid,A,(2007)A detailed modeling method for photovoltaic cells. Energy,32,1724-1730.

Chow,T.T.,He,W., \& Ji,J.(2006) Hybrid photovoltaicthermosyphon water heating system for residential application. Solar Energy, 80,298-306.

Dale,N.V.,Mann,M.D.,\&Salehfar,H.(2008)Semi-empirical model based on thermodynamic principles for determining $6 \mathrm{~kW}$ PEM electrolyzer stack characteristics.Journal of Power Sources, 185(2), 1348-1353.

Dorer,V.,Weber,R.,\&Weber,A.(2005)Performance assessment of fuel cell micro-cogeneration systems for residential buildings.Energy and Buildings,37,1132-1146.

Elhadidy,M.A.(2002)Performance evaluation of hybrid (wind/solar/diesel) power systems.Renewable Energy,26,401 413

ElShatter,Th.F.,Eskandar,M.N.,\&ElHagry,M.T.(2002)Hybrid PV/Fuel cell system design and simulation. Renewable Energy,27(3),479-485.

Galli,S.,\&Stefanoni,M.(1997)Development of a solar hydrogen cycle in Italy.International Journal of Hydrogen Energy,22(5), 453-458.

Ganguly, A., Misra, D., \& Ghosh, S.(2010)Modeling and analysis of solar photovoltaic-electrolyzer-fuel cell hybrid power system integrated with floriculture greenhouse, Energy and Buildings, 42, 2036-2043.

Hawkes,A.D.,Aguiar,P.,HernandezAramburo,C.A.,Leach,M.A.,Brandon,N.P.,Green,T.C.,\&Adji man,C.S.(2006)Techno-economic modelling of a solid oxide fuel cell stack for micro combined heat and power.Journal of Power Sources, 156,321-333.

Hayre,R.O.,Cha,S.W.,Colella,W.,\&Prinz,F.B.(2006)Fuel Cell Fundamentals,John Wiley\& Sons, Inc, USA.

Kandlikar,S.G.,\&Lu,Z.(2009)Fundamental research needs in combined water and thermal management within a proton exchange membrane fuel cell stack under normal and coldstart conditions. Journal of Fuel Cell Science and Technology, 6,044001-(1-13).

Kelly,N.A.,Gibson,T.L.,\&Ouwerkerk,D.B.(2008)A solar powered high efficiency hydrogen fueling system using high pressure electrolysis of water: design and initial results.International Journal of Hydrogen Energy,33(11),2747-2764.

Kelly,N.A.,Gibson,T.L.,\&Ouwerkerk,D.B.(2011)Generation of high-pressure hydrogen for fuel cell electric vehicles using photovoltaic-powered water electrolysis. International Journal of Hydrogen Energy,36,15803-15825.

Li,C.,Zhu,X.,Cao,G.,Sui,S.,\&Hu,M.(2009)Dynamic modeling \& sizing optimization of stand-alone photovoltaic power systems using hybrid energy storage technology.Renewable Energy,34(3),815-826.

Manolakos,D.,Papadakis,G.,Papantonis,D.,\&Kyritsis,S.(2001)A simulation-optimisation programme for designing hybrid energy systems for supplying electricity and fresh water through desalination to remote areas: Case study: the Merssini village, Donoussa island, Aegean Sea, Greece.Energy,26(7),679-704, 2001.

Nafion membranes-Fuel cell Etc.(2016) http://www.fuelcellsetc.com/store/Nafion.Accessed on 6.5.2016.

Nfah,E.M.,Ngundam,J.M.,\&Tchinda,R.(2007)Modelling of solar/diesel/battery hybrid power systems for far-north Cameroon. Renewable Energy,32,832-844.

Nfah,E.M.,Ngundam,J.M.,Vandenbergh,M.,\&Schmid,J.(2008)Si mulation of off-grid generation options for remote villages in Cameroon. Renewable Energy,33, 1064-1072,2008.

Nfah,E.M.,\&Ngundam,J.M.(2008)Modelling Cameroon.Energy Conversion and Management, 49,12951301.

Paksoy,H.O.,Andersson,O.,Abaci,S.,Evliya,H.,\&Turgut,B.(2000) Heating and cooling of a hospital using solar energy coupled with seasonal thermal energy storage in an aquifer.Renewable Energy,19,117-122.

Pal,P.(2004)Modeling of integrated solar photovoltaic fuel cell power generation system.Master of Engineering Thesis,Bengal Engineering \& Science University, Shibpur, Howrah.

Patra,S.K.,\&Datta,P.P.(2009)Some insights into solar photovoltaics-solar home lighting system, NABARD Technical Digest 7,http://www.nabard.org.Accessed on 26.06.2009.

SahebKoussa,D.,Haddadi,M.,\&Belhamel,M.(2009)Economic and technical study of a hybrid system (wind-photovoltaicdiesel) for rural electrification in Algeria.Applied Energy, 86(7-8), 1024-1030.

Shapiro,D.,Duffy,J.,Kimble,M.,\&Pien,M.(2005)Solar-powered regenerative PEM electrolyzer/ fuel cell system. Solar Energy,79(5),544-550.

Solar photovoltaic modules pm 150(2011),http:celindiacoin.preview1.cp247.net/cal/PM150.pdf.Accessed on 1.11.2011

Solis,I.N.,Almendra,L.V.,\&Gallegos,A.A.(2010) $\mathrm{H}_{2}$ production by PEM electrolysis, assisted by textile effluent treatment and a solar photovoltaic cell.International Journal of Hydrogen Energy,35,10833-10841.

Telecommunication Engineering Centre (TEC), New Delhi.(2011), Planning and maintenance guidelines for SPVpower,http://www.tec.gov.in/guidelines.html .Accessed on 23.03.2011.

Tiwari,G.N.(2004)Solar energy Fundamentals,Design, Modeling and Applications, Narosa Publishing House, New Delhi.

Uzunoglu,M.,Onar,O.C.,\&Alam,M.S.(2009)Modeling, control and simulation of a $\mathrm{PV} / \mathrm{FC} / \mathrm{UC}$ based hybrid power generation system for stand-alone applications. Renewable Energy,34(3),509-520.

Veziroglu,A.,\&Macario,R.(2011)Fuel cell vehicles: State of the art with economic and environmental concerns.International Journal of Hydrogen Energy,36, 25-43.

Wies,R.W.,Johnson,R.A.,Agrawal,A.N.,\&Chubb,T.J.(2005)Simuli nk model for economic analysis and environmental impacts of a PV with diesel-battery system for remote villages.IEEE Transactions on Power Systems,20(2),692-700.

Wind speed in Kolkata,West Bengal 700001,India.(2014),http://www.synergyenviron.com/tools/wi nd_data.asp?loc=Kolkata $\% 2$ CWest+Bengal\%2CIndia.Accesse d on 12.10 .2014

Wu,S.H.,Kotak,D.B.,\&Fleetwood,M.S.(2005)An integrated system framework for fuel cell-based distributed green energy applications.Renewable Energy,30,1525-1540.

Yoshida,S.,Ito,K.,\&Yokoyama,R.(2007)Sensitivity analysis in structure optimization of energy supply systems for a hospital.Energy Conversion and Management,48,2836-2843.

Zervas,P.L.,Sarimveis,H.,Palyvos,J.A.,\&Markatos,N.C.G.(2008) Model based optimal control of a hybrid power generation 
Int. Journal of Renewable Energy Development 6 (2) 2017: 181-191

system consisting of photovoltaic arrays and fuel cells. Journal of Power Sources,181(2),327-338.
Zhai,H.,Dai,Y.J.,Wu,J.Y.,\&Wang,R.Z.(2009)Energy and exergy analyses on a novel hybrid solar heating, cooling and power generation system for remote areas. Applied Energy,86(9),1395-1404. 